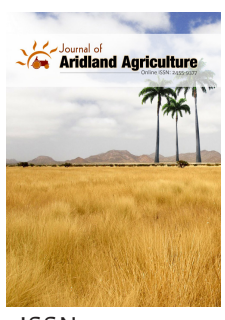

ISSN: $2455-9377$
Received: May 27, 2020 Accepted: July 30, 2020 Published: August 02, 2020

*Corresponding Author: Maysoun M. Saleh, E-mail: mzainsamasaleh@ gmail.com

\section{Multi-environmental evaluation of wheat tetraploid genotypes for agronomic traits under rainfed conditions in Syria}

\author{
Maysoun M. Saleh*, Walid A. Ali², Mohammed H. Alwan³, Zaeda Alsayd Suliman', \\ Rajaa Kenaan ${ }^{5}$, Husain Daiub² and Khaled F. M. Salem ${ }^{6,7}$
}

\begin{abstract}
${ }^{1}$ Genetic Resources Department, General Commission for Scientific Agricultural Research, Damascus, Syria, ${ }^{2}$ Tartous Agricultural Centre, General Commission for Scientific Agricultural Research, Tartous, Syria, ${ }^{3}$ College of Agriculture, University of Muthanna, Ministry of Higher Education and Scientific Research, Iraq, ${ }^{4} \mathrm{Homs}$ Agricultural Centre, General Commission for Scientific Agricultural Research, Homs, Syria, ${ }^{5} \mathrm{Al}-\mathrm{Sw}$ waida Agricultural Centre, General Commission for Scientific Agricultural Research, Al-Swaida, Syria, ${ }^{6}$ Plant Biotechnology Department, Genetic Engineering and Biotechnology Research Institute (GEBRI), P.O. Box, 79, Sadat City, Menoufia University, Egypt, 'Department of Biology, College of Science and Humanities, Shaqra University, Qwaieah, Saudi Arabia
\end{abstract}

\begin{abstract}
This study was conducted at Homs, Al-Swaida and Tartous, General Commission for Scientific Agricultural Research, Syria during 2016/2017 season. Seven wheat genotypes were planted under rainfed conditions in randomized complete block design with three replications. Studied traits were days to maturity, plant height, number of grain per spike, grain weight per spike, 1000 kernal weight and grain yield per plant to evaluate variance between genotypes and locations. Results showed existence of high variance between studied genotypes in all traits especially plant height. It resulted that genotype W45193 was significantly superior in grain yield per plant with an increasing rate of $69.62 \%$ comparing to control Sham 5. Also, it was significantly superior in spike numbers with an increasing rate of $53.53 \%, 57.24 \%$ compared to both controls Sham 3 and Sham 5, respectively. Genotype W45064 was significantly superior in grain weight per spike and 1000 kernal weight compare to both controls Sham 3 and Sham 5. W 45194 was significantly superior in 1000 kernal weight comparing to control Sham $5(36.34,31.16$ g), respectively. Furthermore, all studied traits (except spike number per plant) were more significant in Tartous compare to both Homs and Al-Swaida.
\end{abstract}

KEYWORDS: Genotypes, locations, rainfed, tetraploid wheat, agronomic traits

\section{INTRODUCTION}

Durum wheat is considered as the most important crop in the Mediterranean region [1], where the cultivated area is about $40 \%$ of the world cultivated area of durum wheat [2]. Durum wheat contributes to the improvement of the food industry like biscuits, pasta and healthy children food [3]. Breeding programs of durum wheat receive remarkable attention from Scientists [4] to develop high-yield new varieties adapted to different environments [5]. Recent varieties of wheat are described on a narrow genetic basis, so it is necessary to evaluate more different genotypes to find out new variations and exploit them in a breeding program [6]. In genetic resources programs, the attention to the first ancient cultivated types of wheat or socalled primitive wheat has increased globally for their importance especially in the aspect of healthy food [7]. Wheat breeders specified Triticum polonicum as a proper genetic resource to enhance nutrition value of modern varieties of wheat, and could be used in genetic bio-fortification of durum wheat and bread wheat [8]. Triticum carthlicum has been recommended as one of the best favorable donors to improve bread wheat $[9,10]$. The usage of ancient wheat (Triticum polonicum and Triticum carthlicum) in hybridization with new wheat varieties is effective under drought stress environments as mentioned by [11] Many researchers found significant variations in maturity, plant height and grain weight between durum wheat genotypes [12]. Significant variations were found in grain yield between wheat genotypes and locations and the interaction between them [13]. Results of [14] showed variations in many traits such as grain yield, spike number and plant height between different durum wheat genotypes. After evaluating many wheat genotypes, [15] found that the significant variations in the grain yield and

Copyright: (-) The authors. This article is open access and licensed under the terms of the Creative Commons Attribution License (http://creativecommons.org/licenses/by/4.0/) which permits unrestricted, use, distribution and reproduction in any medium, or format for any purpose, even commercially provided the work is properly cited. Attribution - You must give appropriate credit, provide a link to the license, and indicate if changes were made. 
1000 kernal weight could be used in a breeding program. [16] studied some agronomic and quantity traits between 21 wheat genotypes, their results referred to significant variations in all studied traits such as spike number, weight and number of grains per spike, 1000 kernal weight and grain yield. Also, [17] and [18] found important variations in spike number, spike length, spike peduncle length and grain number per spike between wheat genotypes which were evaluated in many environments. The objectives of this research were to (i) evaluate the variance in studied traits between local and exotic ancient genotypes and locations, (ii) define the best genotypes (in studied traits) and (iii) broaden the narrow genetic basis in recent cultivated varieties.

\section{MATERIALS AND METHODS}

\section{Plant Material}

Seven wheat genotypes (five ancient cultivated wheats) and two improved varieties sham 3 and sham 5 used as controls since they are both high yielded and drought tolerant) originated from different countries were used in this study (Table 1). Genotypes are conserved in the national Syrian genebank at the general commission for scientific agricultural research (GCSAR), Syria.

\section{Field Experiments}

This study was conducted at the three research centers in Homs (middle of Syria), Al-Swaida (Southern Syria) and Tartous (Western Syria) which all belong to the general commission for scientific agricultural research (GCSAR), Syria during the 2016/2017 growing season under rainfed condition in a randomized complete block design (RCBD), with three replicates, all agronomic practices were applied at each location according to the recommendations of Syrian agrarian ministry.

Table 1: List of wheat genotypes used in this study

\begin{tabular}{llll}
\hline No & Genotype name & Scientific name & Origin \\
\hline 1 & W 45049 & Triticum carthlicum & Turkey \\
2 & W 45057 & Triticum carthlicum & Turkey \\
3 & W 45064 & Triticum carthlicum & Syria \\
4 & W 45193 & Triticum polonicum & CIM M YT (unknown origion) \\
5 & W 45194 & Triticum polonicum & CIM MYT (unknown origion) \\
6 & Sham 3 & Triticum durum & Syria \\
7 & Sham 5 & Triticum durum & Syria \\
\hline
\end{tabular}

Each plot contained six rows, $1 \mathrm{~m}$ length, $25 \mathrm{~cm}$ distance between rows and $5 \mathrm{~cm}$ distance between plants in the same row. The depth of planting was $3-5 \mathrm{~cm}$. The following traits were studied at plant maturity: Days to maturity, plant height $(\mathrm{cm})$, spike number per plant, grain number per spike, grain weight per spike (g), 1000 kernal weight(g) and grain yield per plant (g) [19].

\section{Statistical Analysis}

Results analysis was made using Genstat.12 analytical program using the least significant differences test (LSD) at 0.05 in studied traits for comparison between genotypes and between locations.

\section{RESULTS}

Analysis of variance at 0.05 revealed significant variations between genotypes and locations and their interaction in all studied traits (Table 2). The mean of studied traits at three locations is recorded in Table 3. Change percent of trait means comparing to both controls are reported in Table 4 , in which

Change $\%=$ ("mean of trait - mean of control" / mean of control) * 100 .

\section{Days to Maturity}

Genotypes ranged from the earliest matured Sham 5 with 141 days to the latest matured W 45064 with 149.9 days, with a grand mean 144.52 day (Table 3$)$. Although significant variation was found between genotypes, none of the ancient wheat was superior compared to both controls Sham 5 and Sham 3 which needed 141.0, 141.3 days, respectively to maturity (Table 4). Plants were significantly earliest matured at Tartous (130.86 days) compared to Al-Swaida location 139.29 days, and Homs 163.43 days, respectively (Fig. 1).

\section{Plant Height}

Variation was found between genotypes in plant height which ranged from the shortest plants $68.51 \mathrm{~cm}$ in control Sham 3 to the tallest plants $102.01 \mathrm{~cm}$ (W 45064), with grand mean $85.79 \mathrm{~cm}$. Three genotypes (W45064, W45193 and W45057) had plant height (102.1, 97.64 and 92.77) cm, respectively afforded significant accumulation in plant height reached to $48.89,42.52$ and $35.41 \%$ compare to control Sham 3 which had

Table 2: Analysis of variance for studied traits

\begin{tabular}{|c|c|c|c|c|c|c|c|}
\hline \multirow{2}{*}{$\begin{array}{l}\text { Source of } \\
\text { Variation }\end{array}$} & \multirow[t]{2}{*}{$\mathrm{df}$} & \multicolumn{6}{|c|}{ Mean square } \\
\hline & & MD & $\mathrm{PH}$ & SNP & GNP & TKW & GYP \\
\hline G & 6 & $98.21^{\mathrm{s}}$ & $1370.26^{5}$ & $21.482^{\mathrm{s}}$ & $133.29^{\mathrm{s}}$ & $653.08^{s}$ & $65.86^{s}$ \\
\hline $\mathrm{L}$ & 2 & $6001.86^{5}$ & $22063.49^{s}$ & $194.79^{\mathrm{s}}$ & $2635.40^{\mathrm{s}}$ & $1120.12^{\mathrm{s}}$ & $1238.67^{\mathrm{s}}$ \\
\hline$G \times L$ & 12 & $39.73^{s}$ & $646.06^{\mathrm{s}}$ & $21.535^{\mathrm{s}}$ & $177.84^{\mathrm{s}}$ & $107.31^{\mathrm{s}}$ & $58.32^{\mathrm{s}}$ \\
\hline L.S.D G & & 1.757 & 7.051 & 2.450 & 7.198 & 3.232 & 5.839 \\
\hline L.S.D L & & 1.150 & 4.616 & 1.604 & 4.712 & 2.116 & 3.822 \\
\hline L.S.D. $G \times L$ & & 3.043 & 12.213 & 4.244 & 12.467 & 5.598 & 10.113 \\
\hline
\end{tabular}

Where: df degree of freedom, G genotype, L location, L.S.D least significant differences, MD days to maturity, PH plant height, SNP spike number per plant, GNP grain number per spike, TKW 1000 kernal weight, GYP grain yield per plant. ${ }^{5}$ significant 
Table 3: Means of studied traits at three locations

\begin{tabular}{|c|c|c|c|c|c|c|c|c|}
\hline \multirow[t]{2}{*}{ Genotype } & \multicolumn{4}{|c|}{$\mathrm{MD}$} & \multicolumn{4}{|c|}{$\mathrm{PH}$} \\
\hline & $\mathrm{Ho}$ & AIS & Tar & Mean & $\mathrm{Ho}$ & AIS & Tar & Mean \\
\hline W45049 & 164.33 & 138.33 & 130.00 & $144.2^{c}$ & 54.77 & 51.90 & 114.90 & $73.86^{d}$ \\
\hline W45057 & 162.00 & 136.67 & 130.00 & $142.9^{b c}$ & 94.33 & 55.47 & 128.50 & $92.77^{b}$ \\
\hline W45064 & 169.00 & 140.67 & 140.00 & $149.9^{\mathrm{e}}$ & 92.33 & 64.80 & 148.90 & $102.01^{\mathrm{a}}$ \\
\hline W45193 & 164.33 & 139.33 & 140.00 & $147.9^{d}$ & 89.17 & 57.10 & 146.67 & $97.64^{\mathrm{ab}}$ \\
\hline W45194 & 162.00 & 141.33 & 130.00 & $144.4^{c}$ & 62.73 & 58.67 & 130.93 & $84.11^{c}$ \\
\hline Sham3 & 162.00 & 139.00 & 123.00 & $141.3^{\mathrm{ab}}$ & 65.63 & 54.00 & 85.90 & $68.51^{d}$ \\
\hline Sham5 & 160.33 & 139.67 & 123.00 & $141.0^{\mathrm{a}}$ & 86.43 & 64.33 & 94.10 & $81.62^{c}$ \\
\hline Mean & $163.43^{c}$ & $139.29^{b}$ & $130.86^{\mathrm{a}}$ & 144.52 & $77.91^{\mathrm{b}}$ & $58.04^{c}$ & $121.41^{\mathrm{a}}$ & 85.79 \\
\hline \multirow[t]{2}{*}{ Genotype } & \multicolumn{4}{|c|}{ SNP } & \multicolumn{4}{|c|}{ GNS } \\
\hline & $\mathrm{Ho}$ & AIS & Tar & Mean & $\mathrm{Ho}$ & AIS & Tar & Mean \\
\hline W45049 & 7.73 & 4.33 & 10.03 & $7.367^{b}$ & 25.37 & 44.67 & 41.67 & $37.23^{b}$ \\
\hline W45057 & 9.77 & 4.33 & 9.10 & $7.733^{b}$ & 28.53 & 39.33 & 36.00 & $34.62^{b}$ \\
\hline W45064 & 7.83 & 3.67 & 6.33 & $5.944^{b}$ & 19.50 & 34.67 & 56.00 & $36.72^{b}$ \\
\hline W45193 & 19.07 & 5.67 & 7.87 & $10.867^{a}$ & 26.60 & 37.33 & 46.00 & $36.64^{b}$ \\
\hline W45194 & 13.97 & 4.67 & 5.37 & $8.000^{b}$ & 19.47 & 33.33 & 46.00 & $32.93^{b}$ \\
\hline Sham3 & 8.07 & 6.00 & 7.17 & $7.078^{b}$ & 29.33 & 60.00 & 45.67 & $45.00^{\mathrm{a}}$ \\
\hline Sham5 & 9.97 & 5.33 & 5.43 & $6.911^{\mathrm{b}}$ & 22.84 & 54.68 & 39.32 & $38.94^{\mathrm{ab}}$ \\
\hline Mean & $10.91^{\mathrm{a}}$ & $4.86^{c}$ & $7.33^{b}$ & 7.70 & $24.52^{b}$ & $43.43^{a}$ & $44.38^{a}$ & 37.44 \\
\hline \multirow[t]{2}{*}{ Genotype } & \multicolumn{4}{|c|}{ TKW } & \multicolumn{4}{|c|}{ GYP } \\
\hline & $\mathrm{Ho}$ & AIS & Tar & Mean & $\mathrm{Ho}$ & AIS & Tar & Mean \\
\hline W45049 & 29.80 & 32.63 & 31.83 & $31.42^{\mathrm{de}}$ & 4.42 & 6.60 & 14.84 & $8.62^{c}$ \\
\hline W45057 & 37.43 & 31.62 & 39.97 & $36.34^{c}$ & 10.43 & 5.02 & 20.97 & $12.14^{\mathrm{abc}}$ \\
\hline W45064 & 57.87 & 44.18 & 64.33 & $55.46^{\mathrm{a}}$ & 9.52 & 5.61 & 29.90 & $15.01^{\mathrm{ab}}$ \\
\hline W45193 & 28.00 & 26.13 & 46.77 & $33.63^{\text {cde }}$ & 14.67 & 4.17 & 28.25 & $15.69^{\mathrm{a}}$ \\
\hline W45194 & 38.63 & 30.31 & 53.33 & $40.76^{b}$ & 10.52 & 7.13 & 17.80 & $11.82^{\mathrm{abc}}$ \\
\hline Sham 3 & 29.37 & 28.70 & 45.50 & $34.52^{\mathrm{cd}}$ & 7.77 & 10.33 & 22.96 & $13.69^{a b c}$ \\
\hline Sham5 & 29.37 & 28.70 & 45.50 & $31.16^{\mathrm{e}}$ & 4.09 & 10.47 & 13.18 & $9.25^{b c}$ \\
\hline Mean & $34.44^{b}$ & $32.44^{b}$ & $45.97^{\mathrm{a}}$ & 37.61 & $8.77^{b}$ & $7.05^{b}$ & $21.13^{\mathrm{a}}$ & 12.32 \\
\hline
\end{tabular}

Where: Ho Homs, AIS AISwaida, Tar Tartous, MD days to maturity, PH plant height, SNP spike number per plant, GNS grain number per spike, TKW 1000 kernal weight, GYP grain yield per plant

plant height $(68.51) \mathrm{cm}$. The later genotypes also had an increase in plant height in rate of $24.98,19.63$ and $13.66 \%$ compared to the second control Sham 5 which its plant height was $81.62 \mathrm{~cm}$. Also, the genotype W 45194 with plant height $84.11 \mathrm{~cm}$ showed a significant increase rate of $22.77 \%$ comparing to Sham 3. Also, results revealed that the mean of plant height at Tartous was significantly the highest, then at Homs and finally at Al-Swaida with 121.41, 77.91 and $58.04 \mathrm{~cm}$, respectively (Figure 1).

\section{Spike Number per Plant}

This trait varied from the lowest value (5.944 spikes per plant) in the genotype W45064 to the highest value of (10.867 spikes per plant) in the genotype W45193, with a grand mean of 7.70 spike per plant. It resulted that the genotype W45193 was significantly superior in spikes per plant (10.867) with an increased rate of $53.53 \%$ compare to control Sham 3 that had (7.078 spikes per plant), and $57.24 \%$ compare to control Sham 5 which had (6.911 spikes per plant). Spike number per plant was significantly higher at Homs, followed by Tartous, then Al-Swaida 10.91, 7.33 and 4.86 spike, respectively (Figure 2).

\section{Grain Number per Spike}

The range of grain number per spike varied from 32.93 grains per spike in the genotype W 45194 to 45.00 grains per spike in control

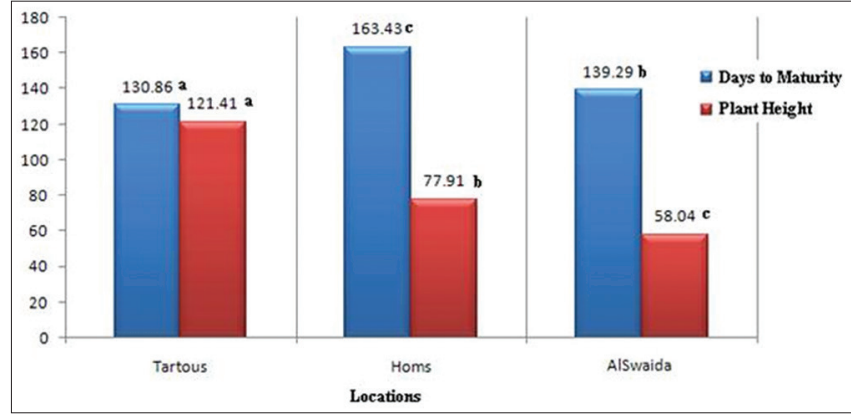

Figure 1: Variation in days to maturity and plant height between locations.

Where: a, b, c refers to the sort of means at significans level 0.05 (ascending for days to maturity and descending for plant height)

Sham 3, with a grand mean 37.44 grains per spike. Results showed that none of the genotypes were significantly superior compared to both controls. Grain number per spike was higher at both Tartous and Al-Swaida with no significant differences $(44.38,43.43$ grains per spike, respectively). However, at Homs 24.52 grain per spike with significant differences compared to other locations (Figure 2).

\section{Kernal Weight}

Genotypes differed in 1000 kernal weight from the lowest weight of $31.16 \mathrm{~g}$ in control Sham 5 to the highest weight of $55.46 \mathrm{~g}$ in the 
Table 4: Chang\% of trait means comparing to controls

\begin{tabular}{|c|c|c|c|c|c|c|}
\hline \multirow[t]{2}{*}{ Genotype } & \multirow{2}{*}{$\begin{array}{c}\text { Mean } \\
\text { MD } \\
\end{array}$} & \multicolumn{2}{|c|}{$\begin{array}{c}\text { Change \% } \\
\text { comparing to }\end{array}$} & \multirow{2}{*}{$\begin{array}{c}\text { Mean } \\
\mathrm{PH} \\
\end{array}$} & \multicolumn{2}{|c|}{$\begin{array}{c}\text { Change\% } \\
\text { comparing to }\end{array}$} \\
\hline & & Sham3 & Sham5 & & Sham3 & Sham5 \\
\hline W45049 & 144.2 & 2.05 & 2.27 & 73.86 & 7.81 & -9.51 \\
\hline W45057 & 142.9 & 1.13 & 1.35 & 92.77 & 35.41 & 13.66 \\
\hline W45064 & 149.9 & 6.09 & 6.31 & 102.01 & 48.90 & 24.98 \\
\hline W45193 & 147.9 & 4.67 & 4.89 & 97.64 & 42.52 & 19.63 \\
\hline W45194 & 144.4 & 2.19 & 2.41 & 84.11 & 22.77 & 3.05 \\
\hline Sham3 & 141.3 & & & 68.51 & & \\
\hline Sham5 & 141.0 & & & 81.62 & & \\
\hline Genotype & & SNP & & & GNS & \\
\hline W45049 & 7.367 & 4.08 & 6.60 & 37.23 & -17.27 & -4.39 \\
\hline W45057 & 7.733 & 9.25 & 11.89 & 34.62 & -23.07 & -11.09 \\
\hline W45064 & 5.944 & -16.02 & -13.99 & 36.72 & -18.40 & -5.70 \\
\hline W45193 & 10.867 & 53.53 & 57.24 & 36.64 & -18.58 & -5.91 \\
\hline W45194 & 8.000 & 13.03 & 15.76 & 32.93 & -26.82 & -15.43 \\
\hline Sham3 & 7.078 & & & 45.00 & & \\
\hline Sham5 & 6.911 & & & 38.94 & & \\
\hline Genotype & & TKW & & & GYP & \\
\hline W45049 & 31.42 & -8.98 & 0.86 & 8.62 & -37.03 & -6.81 \\
\hline W45057 & 36.34 & 5.27 & 17.18 & 12.14 & -11.32 & 31.24 \\
\hline W45064 & 55.46 & 60.66 & 80.57 & 15.01 & 9.64 & 62.27 \\
\hline W45193 & 33.63 & -2.58 & 8.19 & 15.69 & 14.61 & 69.62 \\
\hline W45194 & 40.76 & 18.08 & 31.83 & 11.82 & -13.66 & 27.78 \\
\hline Sham3 & 34.52 & & & 13.69 & & \\
\hline Sham5 & 31.16 & & & 9.25 & & \\
\hline
\end{tabular}

Where: MD days to maturity, PH plant height, SNP spike number per plant, GNS grain number per spike, TKW 1000 kernal weight, GYP grain yield per plant.

Table 5: Rainfall and temperature at three locations of this study during 2016/2017

\begin{tabular}{llccccccc}
\hline Location & & Sept & Jan & Feb & Mar & Apr & May & Sum \\
& & 2016 & 2017 & 2017 & 2017 & 2017 & 2017 & \\
\hline Homs & R & 114 & 72.5 & 5.7 & 49.5 & 3.7 & - & 245.4 \\
& H-T & 10.6 & 10.7 & 14.3 & 17.4 & 23 & 26.9 & \\
\multirow{5}{*}{ Tartous } & L-T & 4.4 & 3.2 & 2.8 & 8 & 10.9 & 15.6 & \\
& R & 277 & 194.5 & 6 & 92 & 18 & - & 587.5 \\
& H-T & 15.45 & 14.4 & 15.24 & 18.7 & 22.7 & 26.16 & \\
Al-Swaida a & L-T & 7.8 & 6.58 & 7.33 & 12.45 & 11.2 & 14.83 & \\
& R & 126.3 & 43.9 & 20.8 & 39.6 & 5.9 & - & 236.5 \\
& H-T & 13.74 & 13.87 & 17.4 & - & 28.20 & 33.90 & \\
& L-T & 4.55 & 4.35 & 4.86 & - & 13.20 & 17.71 & \\
\hline
\end{tabular}

Where R Rainfall (mm), H-T Highest temperature, L-T Lowest

Temperature

genotype W 45064 with a grand mean of $37.61 \mathrm{~g}$. The genotype W45064 was significantly superior in 1000 kernal weightwith an increased rate of $60.66,80.57 \%$ comparing to both controls Sham 3 and Sham 5 (Table 4). Also, the genotype W 45194 was significantly superior with an increased rate of $18.08,31.83 \%$ compared to both controls Sham 3 and Sham 5, as well as the genotype W 45057, which was significantly superior with an increased rate $17.18 \%$ comparing to control Sham 5. 1000 kernal weightat Tartous was significantly the highest with $45.97 \mathrm{~g}$, followed by both Homs and Al-Swaida 34.44, 32.44g, respectively (Figure 3).

\section{Grain Yield Per Plant}

Grand mean for grain yield per plant was $12.32 \mathrm{~g}$, the range varied from $8.62 \mathrm{~g}$ in the genotype W 45049 to $15.69 \mathrm{~g}$ in the

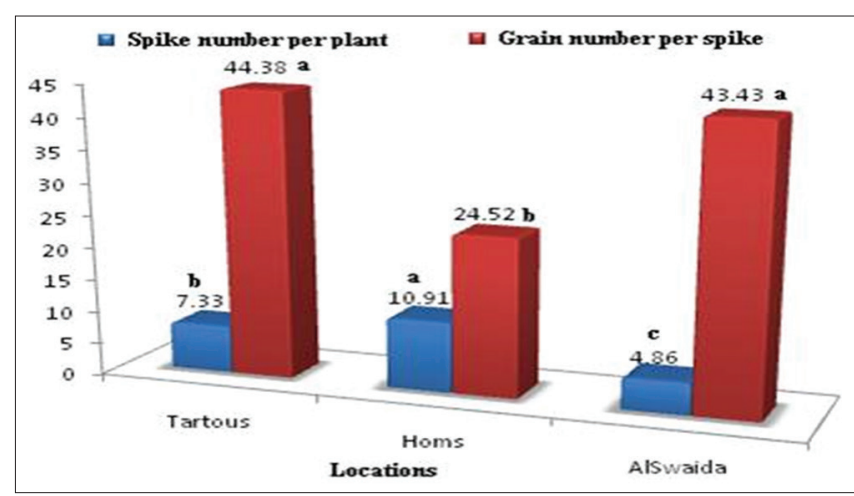

Figure 2: Variation in spike number per plant and grain number per spike between locations.

Where: $a, b, c$ refers to the descending sort of means at significans level 0.05

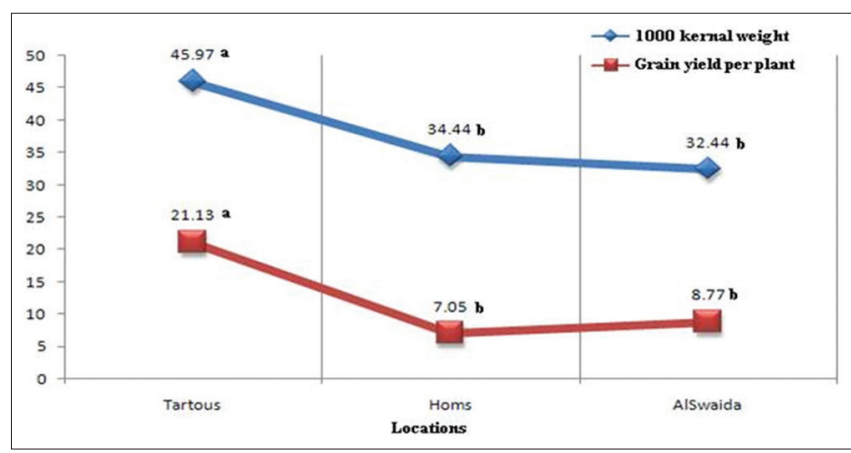

Figure 3: Variation in 1000 kernal weight and grain yield between locations.

Where: $a, b, c$ refers to the descending sort of means at significans level 0.05

genotype W 45193 (Table 3). Results showed that the genotype W 45193 was significantly superior in the grain yield per plant (15.69) $\mathrm{g}$ with an increased rate of $69.62 \%$ compared to the control Sham 5 (9.25 g) (Table 4). Grain yield per plant at Tartous was significantly higher with $21.13 \mathrm{~g}$, followed by both of Homs and Al-Swaida (8.77 and 7.05 g respectively), (Figure 3).

\section{DISCUSSION}

Results showed the existence of high variability between genotypes in all studied traits, which agree with the results of many researchers who reported about the presence of high variability between wheat genotypes in many traits such as days to maturity [12], plant height [20], spike number per plant [21], grain number per spike [22], 1000 kernal weight [16] and grain yield per plant $[23,13]$. Results revealed that the genotype W45193 was superior in the spike number per plant and this could be a result of having taller plants compared to other genotypes. This is in agreement with other scientist's results who found that spike number per plant increased when increasing plant height [24]. Regarding 1000 kernal weight, both genotypes W45194 and W45057 were superior compared to controls and this could result in more spikes number per plant and to genetic variation [25]. The genotype W45193 was superior in grain yield as a result of being superior in two yield components which are spike number per plant and 1000 kernal 
weight comparing to controls. All studied traits were significant $[26,27]$ and The best was at Tartous location because of the high amount of total rainfall which was almost more than the rainfall in both other locations (Table 5), and water, as it is known, is the main reason for plant cell elongation and plant growth [28, 29].

\section{CONCLUSION}

In this study, high variability was found between studied genotypes which could be exploited in a breeding program, as the W45193 genotype was superior in the grain yield per plant and three genotypes W45064, W45057 and 45194 were superior in 1000 kernal weight. The genotype W45193 was superior in spike number per plant. Tartous location was the best for most studied traits.

\section{REFERENCES}

1. Desiderio, F., Zarei, L., Licciardello, S., Cheghamirza, K., Farshadfar, E., Virzi, N., Sciacca, F., Bagnaresi, P., Battaglia, R., Guerra, D., Palumbo, M., Cattivelli, L., \& Mazzucotelli, E. (2019). Genomic regions from an Iranian landrace increase kernel size in durum wheat. Frontiers in plant science, 10, 448. http://doi: 10.3389/fpls.2019.00448

2. Bassi, F. M., Brahmi, H., Sabraoui, A., Amri, A., Nsarellah, N., Nachit, M. M., Al-Abdallat, A., Chen, M. S., Lazraq, A., \& El Bouhssini, M. (2019). Genetic identification of loci for Hessian fly resistance in durum wheat. Molecular breeding, 39(2), 24. https:// doi.org/10.1007/s11032-019-0927-1

3. Sall, A. T., Chiari, T., Legesse, W., Seid-Ahmad, K., Ortiz, R., Van Ginkel, M. \& Bassi, F. M. (2019). Durum wheat (Triticum durum Desf.): Origin, cultivation and potential expansion in sub-saharan Africa. Agronomy, 9, 263. https://doi.org/10.3390/agronomy9050263

4. Fang, C., Ma, Y., Wu, S., Liu, Z., Wang, Z., Yang, R., Hu, G., Zhou, Z., Yu, H., Zhang, M., \& et al. (2017). Genome-wide association studies dissect the genetic networks underlying agronomical traits in soybean. Genome Biology. 18, 161, 1-13. https://doi.org/10.1186/ s13059-017-1289-9

5. Bornhofen, E., Benin, G., Storck, L., Woyann, L. G., Duarte, T., Stoco, M. G., \& Marchioro, S. V. (2017). Statistical methods to study adaptability and stability of wheat genotypes. Bragantia, Campinas, 76(1), 1-10. DOI: http://dx.doi.org/10.1590/1678-4499.557

6. Lopes, S. M., El-Basyoni, I., Baenziger, P. S., Singh, S., Royo, C., Ozbek, K., Aktas, H., Ozer, E., Ozdemir, F., Manickavelu, A., Ban, T., \& Vikram, P. (2015). Exploiting genetic diversity from landraces in wheat breeding for adaptation to climate change. Journal of Experimental Botany, 66(12), 3477-3486. http://doi:10.1093/jxb/erv122

7. Lo Bianco, M.; Siracusa, L.; Dattilo, S.; Venora, G., \& Ruberto, G. (2017). Phenolic fingerprint of Sicilian modern cultivars and durum wheat landraces: A tool to assess with diversity. Cereal Chemistry, 94, 1045-1051. https://doi.org/10.1094/CCHEM-06-17-0125-R

8. Bieńkowska T, Suchowilska E, Kandler et al (2019). Triticum polonicum $\mathrm{L}$. as potential source material for the biofortification of wheat with essential micronutrients. Plant Genetic Resources: Characterization and Utilization, Plant Genet Res17(3):213-220

9. MerkerA, Lantai K(1997) Hybrids between wheats and perennial Leymus and Thinopyrum species. Acta Agric. Scand. Section B: Soil Plant Sci. 47:48-51

10. De MoraesFMIB,Zanatta ACA, Prestes AMV et al (2000) Cytogenetics and immature embryo culture at Embrapa Trigo breeding program: Transfer of disease resistance from related species by artificial resynthesis of hexaploid wheat (Triticum aestivum L. em. Thell). Genet Mol Biol 23:1051-1062

11. Valkoun J. J. 2001. Wheat pre-Breeding using wild progenitors. Euphytica 119:17-23

12. Zemede, A., Mekbib, F., Assefa, K., \& Bishaw, Z. (2019). Variability in Ethiopian durum wheat under rainfed environment subjected to drought at anthesis. Ethiopian Journal of Agricultural Sciences, 29(2), 17-29

13. Akbarzai, D. K., Saharawat, Y., Mohammadi, L., Manan, A. R.,
Habibi, A., Tavva, S., Nigamananda S., \& Singh, M. (2017). Genotype $\times$ environment interaction and identification of high yielding wheat genotypes for Afghanistan. Journal of Experimental Biology and Agricultural Sciences, 5(2), 225-234. http://dx.doi. org/10.18006/2017.5(2).225.234

14. Swami, S., Bazaya, B. R., \& Gurjar, G. N. (2019). Performance of durum wheat (Triticum durum) genotypes under variable sowing dates in sub-tropical zone of Jammu, Jammu \& Kashmir. International Journal of Current Microbiology and Applied Sciences, 8(03), 760-765. https:// doi.org/10.20546/ijcmas.2019.803.093

15. Esmail, R. M., Eldessouky, S. E. L., Mahfouze, S. A., \& ElDemardash, I. S. (2016). Evaluation of new wheat bread lines (Triticum aestivum L.) under normal and water stress conditions. International Journal of Chem Tech Research, 9(5), 89-99.

16. Ebrahimnejad, S., \& Rameeh, V. (2016). Correlation and factor analysis of grain yield and some important component characters in spring bread wheat genotypes. Cercetari Agronomice in Moldova, 1(165), 5-15. http://DOI: 10.1515/cerce-2016-0001

17. Lone, R. A., Dey T., Sharma, B. C., Rai, G. K., Wani, S. H., \& Lone, J. A. (2017). Genetic variability and correlation studies in winter wheat (Triticum aestivum L.) germplasm for morphological and biochemical characters. International Journal of Pure Applied Bioscience, 5(1):8291. http://dx.doi.org/10.18782/2320-7051.2489

18. Azimzadeh, N., Khalilzadeh, G., \& Eivazi, A. R. (2017). Evaluation of source and sink physiological limitation on grain yield and some agronomic traits in promising bread wheat genotypes. International Journal of Pure Applied Bioscience, 5(2), 22-30. http://dx.doi. org/10.18782/2320-7051.2674

19. IPGRI, (1994). Report of the IPGRI workshop on conservation and use of underutilized Mediterranean species, Valenzano (BA), Rome, Italy.

20. Wang, S., Xu, S., Chao, S., Sun, Q., Liu, S., \& Xia, G. (2019). A genomewide association study of highly heritable agronomic traits in durum wheat. Frontiers in Plant Science 10: 919. https://doi: 10.3389/ fpls.2019.00919

21. Othmani, A., Ayed, S., Slama-Ayed, O., Slim-Amara, H., \& Ben Younes, M. (2019). Durum wheat response (Triticum durum Desf.) to drought stress under laboratory conditions. IOSR Journal of Agriculture and Veterinary Science, 12(2), 1-4. http://DOI: 10.9790/2380-1202010104

22. Dutamo, D., Alamerew, S., Eticha, F., \& Assefa, E. (2015). Genetic variability in bread wheat (Triticum aestivum L.) germplasm for yield and yield component traits. Journal Biology, Agriculture and Healthcare, 5(17), 140-147.

23. Ebsa, M. E., Worku, T. B., \& Dugo, T. L. D. (2017). Registration of "Haydaroo" newly released emmer wheat (Triticum dicoccum L.) variety for bale highland areas. American Journal of Life Sciences, 5(5), 145-149. http://doi: 10.11648/j.ajls.20170505.1

24. Subhaschandra, B. (2007). Genetic Analysis in tetraploid wheat. M Sc. thesis, Genetics and Plant Breeding Department, College of Agriculture, University of Agricultural Sciences, Dharwad, India

25. Fiore, M. C., Mercati, F., Spina, A., Blangiforti, S., Venora, G., Dell'Acqua, M., Lupini, A., Preiti, G., Monti, N., Pè, M. E., \& Sunseri, F. (2019). High-throughput genotype, morphology, and quality traits evaluation for the assessment of genetic diversity of wheat landraces from Sicily. Plants 2019, 8, 116. https://DOI:10.3390/plants805011

26. Abbas, G., Khattak, J. Z. K., Abbas, G., Ishaque, M., Aslam, M., Abbas, Z., Amir, M., \& Khokhar, M. B. (2013). Profit maximizing level of potassium fertilizer in wheat production under arid environment Pakistan Journal of Botany, 45(3), 961-965.

27. Kazi, A. G., Rashid A., Mahmood T., \& Kazi, A. M. (2012). Molecular and morphological diversity with biotic stress resistances of high 1000 kernal weightsynthetic hexaploid wheats. Pakistan Journal of Botany, 44(3), 1021-1028.

28. Kiliç, H., \& Yağbasanlar, T. (2010). The effect of drought stress on grain yield, yield components and some quality traits of durum wheat (Triticum Turgidum ssp. durum) cultivars, Notulae Botanicae Horti Agrobotanici Cluj-Napoca 38(1) 164-170. https://DOI: https:// doi.org/10.15835/nbha3814274

29. Tambussi, E. A., Casadesus, J., Munne-Bosch, S., \& Araus, J. L. (2002). Photoprotection in water-stressed plant of durum wheat (Triticum turgidumvar var. durum): Changes in chlorophyll fluorescence, spectral signature and photosynthetic pigments. Functional Plant Biology, 29, 35-44. https://doi.org/10.1071/PP01104 